que sustentei uma questão junto aos tribunais da Califórnia contra a OPEP e contra um dos estadosmembros da organização. A decisão foi muito interessante porque o Tribunal Federal declarou que não tinha jurisdição sobre a organização nem sobre os estados-membros da mesma.

Há uma sentença também recente e muito significativa em conexão com a responsabilidade eventual por perdas e danos causados pela perfuração de um poço de petróleo pela companhia petrolífera mexicana Pemex. Nesse caso, um tribunal do Estado do Texas chegou a estabelecer que, ainda quando a atividade de perfuração possa classificar-se como uma atividade industrial, dentro do contexto da lei de imunidade de soberania se tratava, de acordo com a interpretação do tribunal, da execução ou do cumprimento de uma política do Estado mexicano e, em face disso, declarou não ter jurisdição sobre o caso.

Cito estes casos particulares para provocar uma reflexão, pois cada um destes temas é suficientemente complexo por si só e não é este o momento de entrar em detalhes.

E assim concluirei expressando apenas e de novo o meu agradecimento por ter sido convidado a participar deste encontro tão frutífero, tão interessante e tão estimulante e dizendo-lhes que muito mais do que Ihes transmiti nestes dois dias e o que aprendi aqui, pelo que muita razão têm os que afirmam que se aprende ensinando.

\title{
A importância da escolha da lei do contrato internacional
}

Samia Rashed, doutora em direito internacional (Universidade do Cairo) e consultora-legal em direito internacional.
Samia Rashed

blema do juri imperi, nem do juri gentis, desde que se prova que a empresa pública se não identifica com o governo, o que se determina mediante a lei aplicável, não havendo assim problema quanto à imunidade da dita empresa. Quanto à jurisdição, ao problema da sua determinação, não direi se é melhor a arbitragem, se as decisões dadas pelos tribunais, sendo que a única coisa que se deve ter em mente ao escolher um dos dois sistemas é o problema da execução.

Em muitos países a execução de decisões estrangeirs encontr grandes dificuldades. Há que ter em conta, portanto, as condições locais e ver se são ou não apropriadas. No Egito, por exemplo, deparamos com as mais estranhas condições para executar decisões estrangeiras. Estatui-se aí que "se os tribunais egípcios são competentes ou podiam ser competentes para apreciar o litígio, a decisão estrangeira não pode ser efetivada". Por isso eu nunca aconselharia um cliente meu a recorrer a tribunais estrangeiros numa causa que envolvesse um contratante egípcio. Por outro lado, se optarmos pela arbitragem, quer para fins de efetivação, quer para fins de execução, temos que pensar que existe a Convenção de Nova lorque, realizada em 1958. Muitos países já a ratificaram e a aplicam. Essa convenção oferece um 
processo bem mais fácil de execução de sentenças, muito embora ofereça ainda certas dificuldades. Por isso é necessário comparar, quanto à execução, qual a forma a preferir, qual o instrumento mais fácil de efetivar, se a sentença, se a decisão arbitral. 